$\theta$

Download

UDC 911.3

https://doi.org/10.17721/2308-135X.2020.59.14-21

Batychenko Svitlana Pavlivna,

Candidate of Geographic Sciences National University of Food Technologies, Kyiv, Ukraine

e-mail: batychenko_sveta@ukr.net

Uliganets Sergey Ivanovych,

PhD Geography, Associate Professor Taras Shevchenko National University of Kyiv, Kyiv Ukraine,

e-mail: uliganez@ukr.net

Melnik Lyudmila Viktorivna,

Candidate of Geographic Sciences Taras Shevchenko National University of Kyiv, Kyiv, Ukraine,

e-mail: lysil@ukr.net 


\section{FEATURES OF ORGANIZATION MEDICAL TOURS}

Goal. Disclosure of theoretical aspects of technology and organization of medical tours.

Method. The study is based on general scientific methods, namely, analysis and synthesis, descriptive.

Results. The definition of the concepts "medical tourism" and "health tourism" is revealed, according to which the structure of the medical tourism industry is given. Signs of medical tourism are defined. Elements of the market of medical tourism are defined. It is established that the list of works on creation of a medical tour (product, program) includes: research of the market of potential demand; search for partners; checking the availability of services and establishing the adequacy of previously received information; preparation of agreements (contracts) on cooperation with suppliers / sellers of tourism products and negotiations; information and methodological support of the tour; realization of medical rounds to consumers; registration of documents for travel; direct service of tourists and control over the provision of a certain quantity and quality of services; other types of work. The main stages of development of a medical round are offered. The generalized actions at concrete stages of process of the organization and realization of a medical round are resulted.

Scientific novelty. Generalized measures at specific stages of the process of organization and implementation of the treatment tour. Development of a medical product, includes: marketing research; analysis of market segments and competitors; proposed consumer demand; resort locations; market conditions of tourist services; estimation of real costs for development, advertising and promotion of services.

Practical significance. Based on the study of international experience of spa resorts, in order for sanatoriums of Ukraine to more actively implement progressive international principles and standards of medical tourism, we have developed the following generalized recommendations 
for the management of domestic sanatoriums: to develop variable season tickets for complex medical services; pay attention to the formation of individual training programs with the subsequent control of the instructor; to improve the system of medical service with new programs for a specific material and technical base; to intensify the organization of short-distance tourism in the conditions of sanatorium treatment; systematically improve the network and develop new tourist routes of hiking, cycling, equestrian tourism, terrain routes, Nordic walking; to develop walking medical tourism, hippotherapy.

Keywords: medical tour, medical tourism, medical and health tourism, spa tourism, wellness tourism.

References:

1. Baev, VV Model of medical tourism cluster management // Bulletin of Khmelnytsky National University. Economic Sciences Series. 2015. - № 4. -Vol. 1. - P. 21-26.

2. Baev, VV Characteristics of structural elements of the medical tourism market // Electronic scientific publication "Effective Economy". 2015. - № 3. Access mode:

http://www.economy.nayka.com. ua / ? op $=1 \& z=3891$

3. Vetitnev, AM Kurortnoe delo: Uchebnoe posobie / AM Vetitnev, LB Zhuravleva. M .: KNORUS, 2006. $528 \mathrm{~s}$.

4. Dekhtyar, VD Fundamentals of sports and health tourism / VD Dekhtyar. - K: Scientific World, 2002. - $202 \mathrm{p}$.

5. Zavarika, GM Resort business: textbook. way. / GM Zavarika. - Kyiv: Center for Educational Literature, 2015.

6. Kurortologiya: pidruchnyk / OM Kravets, AA Ryabev; Kharkiv. nat. un-t city. household in 
them. OM Beketova. - Kharkiv: KhNUMG them. OM Beketova, 2017.

7. Kuskov, AS, Listikova, OV Kurortologiya i ozdorovitel'nyi turizm: Uchebnoe posobie / AS Kuskov, OV Listikova. Rostov n / D:

8. Kushniruk, YS Recreation and balneology: textbook / Rivne - 2012. - 103-104 p.

9. Lyubitseva, OO Market of tourist services (geospatial aspects) K .: Alterpress, 2002. $436 \mathrm{p}$.

10. Malska, MP Health tourism // Tourism in the international and national dimensions. History and modernity: Monograph / MP Malskaya, MJ Rutinsky, NM Pankiv. Lviv: LNU Publishing Center named after I. Franko, 2008. S. 191-210.

11. Novikova, VI Sanatorium-resort sphere: infrastructural component, state of development in Ukraine / VI Novikova // Geography and tourism: science. zb. / Kyiv. nat. Univ. Taras Shevchenko. - Kyiv, 2011. - Issue. 16. - P. 93-102. [Electronic resource]. - Access mode: http://nbuv.gov.ua/ UJRN / gt_2011_16_16

12. Rutinsky, M. Classification and typology of resorts // Visnyk of Lviv National University. The series is geographical. 2007. Vip. 34. pp. 236-246.

13. Rutinsky, MJ Geography of health tourism in the Western region of Ukraine at the turn of the XIX-XX centuries. Proceedings of the VII International Conference "Geography, Economics and Tourism: National and International Experience" (October 4-6, 2013) Lviv-Ternopil. Pp. 487-493.

14. Fomenko, NV Recreational resources and balneology: textbook. way. / H.B. Fomenko. Kyiv: Center for Educational Literature, 2007. - 312 p. 
v592

Written by Administrator

Wednesday, 14 April 2021 13:39 - Last Updated Friday, 16 April 2021 12:23

Надійшла до редколегії 08.11.2020 